\title{
História da Cirurgia Abdômino-Pélvica no INCA
}

\author{
The History of Abdominal-Pelvic Surgery at I NCA
}

\author{
Eduardo Linhares Riello de Melloe Darcy da Silva Guimarães`
}

${ }^{1}$ Chefe da Seção de Cirurgia Abdômino Pélvica, H ospital do Câncer I, Instituto N acional de Câncer (INCA). ${ }^{\dagger}$ Assessor do Gabinete da Direção G eral, Instituto N acional de Câncer (INCA).

Até o ano de 1952, o Departamento de Cirurgia Especializada do Instituto de Câncer, unidade subordinada ao então Serviço $N$ acional de Câncer, era unicêntrico. N este ano foram projetadas e criadas as Seções de Cirurgia, cuja divisão obedeceu ao critério de localização topográfica das lesões.

As Seções de Abdome Superior e a de Cólon e R eto tiveram suas chefias entregues aos D rs. Alberto Lima de M oraes C outinho e Luiz Carlos de O liveira Junior, respectivamente. A partir de 1953, a chefia da Seção de Abdome Superior passou à responsabilidade do Dr. Luiz Carlos de O liveira Junior e a da Seção de Cólon e Reto para o Dr. Amador Corrêa Campos, que devido à sua transferência para Brasília em 1961, foi substituído pelo Dr. Helio Duarte Nogueira de Sá.

Ainda em 1961, no dia 28 de janeiro, através do D ecreto $n=50.251$, é aprovado o Regimento do Instituto $N$ acional de $C$ âncer, 0 qual em seu artigo 57 institui 0 Serviço de Cirurgia Especializada, criando no art. 0 58, dentre outras, a Seção de Cirurgia Abdominal Superior e a Seção de Cólon e Reto.

Em 1964, foi instituída a Seção Especializada de Cirurgia Abdominal resultante da fusão da Seção de Abdome Superior e de Cólon e Reto. Para chefiá-la o Diretor do Instituto N acional de Câncer, Prof. Francisco Fial ho, designou o Dr. Luiz Carlos de O liveira Junior.

Com a aposentadoria compulsória do D r. Luiz C arlos de $O$ liveira Junior, em 1964, assumiu a Chefia da Seção de Cirurgia Abdominal, o Dr. Ary Frauzino Pereira. Pioneiro em diversas técnicas de cirurgia oncológica, tem seu nome relacionado ao desenvolvimento desta especialidade, em nível nacional, e empresta seu nome à Fundação Ary Frauzino para Pesquisa e Controle do Câncer - FAF, entidade privada sem finslucrativos, criada com a finalidade de colaborar com o IN CA em todas suas áreas de atuação.

O D r. Ary Frauzino Pereira ocupou o cargo até 1980, quando assumiu a D ireção Geral do IN CA. N o período entre 1980 e 1995, revezaram-se na Chefia da Seção o D r. Alemar Roge Salomão e o Dr. Jurandir Almeida D ias. Durante este período houve a consolidação do serviço do ponto de vista técnico e como um serviço de treinamento em cirurgia oncológica nacionalmente reconhecido.

Em 1995, assumiu a chefia da Seção de Cirurgia Abdômino-Pélvica do HC 1, o Dr. José Humberto Simões Corrêa. Ex-médico residente do IN CA, mestre em cirurgia abdominal veio com uma nova visão para o serviço. Criou um modelo de gerência, baseado numa gestão por qualidade total, no qual o funcionamento do serviço e seus membros norteiam-se em índices de produtividade e qualidade. Este pioneirismo gerou um salto em qualidade que elevou 0 serviço ao posto de centro de referência nacional para as patologias neoplásicas do trato gastrointestinal.

Em Janeiro de 2001, por determinação do D iretor Geral do IN CA, D r. Jacob Kligerman, a Seção de Abdome do HC II integrou-se à Seção de Abdome do HC I, sob a égide do Dr. José H umberto, conforme política de unificação de serviços da Instituição. Esta medida teve como

objetivo a otimização de recursos humanos, materiais e uniformização das condutas terapêuticas.

Em março de 2003 o Dr. Eduardo Linhares Riello 
de M ello assumiu a chefia da Seção. Conforme cronograma estipulado democraticamente entre os membros do serviço, os próximos anos terão como objetivo esal to de qualidade o desenvolvimento científico com a realização de congressos e publicação de artigos científicos preferencialmente em revistas estrangeiras.

\section{C hefes de Seção:}

Dr. Luís Carlos de O liveira Júnior

Dr. Ary Frauzino Pereira

Dr. Alemar Roge Salomão

Dr. Jurandir Almeida Dias

Dr. José H umberto Simões Corrêa 